\title{
UJI EFEKTIFITAS PENAMBAHAN MINYAK IKAN DENGAN DOSIS YANG BERDEDA PADA PAKAN TERHADAP PERTUMBUHAN DAN FCR UDANG VANNAMEI (Litopenaeus vannamei)
}

\author{
Didik Santoso', Andi Rahmad Rahim² \\ 1. Mahasiswa prodi budidaya perikanan, fakultas pertanian universitas muhammadiyah gresik \\ 2. Dosen prodi budidaya perikanan, fakultas pertanian universitas muhammadiyah gresik
}

\begin{abstract}
This research purposed to acquire the best dose of fish oil additional toward vannamei shrimp feed and vannamei shrimp FCR. This research is using group randomized design (GRD) by giving 4 treatments, 3 times repetition and 1 control, from every repetition taken randomly for 4 sample. Every cultivation place spearded vannamei seed size $5-7 \mathrm{~cm}$ with a density of 20 tails $/ \mathrm{m}^{3}$. Applying fish oil toward every treatments of shrimp seed by concentration suitable with the treatments, they are $: M_{0}=$ Control $(0 \mathrm{ml} / \mathrm{kg}), M_{1}=5 \mathrm{ml} / \mathrm{kg} . \mathrm{M}_{2}=10 \mathrm{ml} / \mathrm{kg}$ dan $\mathrm{M}_{3}=$ $15 \mathrm{ml} / \mathrm{kg}$. From research result that has been done, so able to conclude that giving fish oil dose toward vannamei shrimp feed shows a real difference of absolute weight variable and FCR. In treatment $\mathrm{M}_{1}$ ( $5 \mathrm{ml} / \mathrm{kg}$ feed) giving absolute weight and best FCR. Meanwhile, absolute length variables do not show any real difference in all treatments.
\end{abstract}

Keywords: growth, vaname shrimp, feed dose, fish oil.

\begin{abstract}
ABSTRAK
Penelitian ini bertujuan untuk mendapatkan dosis terbaik penambahan minyak ikan pada pakan udang vannamei terhadap pertumbuhan dan FCR udang vannamei. Penelitian ini menggunakan Rancangan Acak kelompok (RAK) dengan 4 perlakuan, 3 kali ulangan dan 1 kontrol, dari setiap ulangan diambil secara acak 4 sampel. Setiap tempat budidaya ditebar benih udang vannamei ukuran $5-7 \mathrm{~cm}$ dengan kepadatan $20 \mathrm{ekor} / \mathrm{m}^{3}$. Aplikasi minyak ikan pada setiap perlakuan pada pakan udang dengan konsentrasi sesuai perlakuan yaitu : $\mathbf{M}_{0}=$ Kontrol $(0$ $\mathrm{ml} / \mathrm{kg}), M_{1}=5 \mathrm{ml} / \mathrm{kg} . \mathrm{M}_{2}=10 \mathrm{ml} / \mathrm{kg}$ dan $M_{3}=15 \mathrm{ml} / \mathrm{kg}$. Dari hasil penelitian yang telah dilakukan, maka dapat disimpulkan bahwa pemberian dosis minyak ikan pada pakan udang vannamei menunjukan perbedaan nyata pada variabel bobot mutlak dan FCR. Pada perlakuan $\mathrm{M}_{1}(5 \mathrm{ml} / \mathrm{kg}$ pakan) memberikan bobot mutlak dan FCR terbaik. Sedangkan variabel panjang mutlak tidak memperlihatkan perbedaan nyata pada semua perlakuan.
\end{abstract}

Kata kunci : pertumbuhan, udang vaname, dosis pakan, minyak ikan. 


\section{PENDAHULUAN}

Udang vannamei merupakan salah satu udang yang mempunyai nilai ekonomis dan merupakan jenis udang alternatif yang dapat dibudidayakan di Indonesia, disamping udang windu (Penaeus monodon) dan udang putih (Penaeus merguensis). Pakan merupakan biaya produksi yang paling besar dalam usaha budidaya udang. Menurut Nababan (2015), biaya yang dikeluarkan untuk pakan pada usaha budidaya mencapai 60-70\% dari total biaya. Sedangkan untuk Konversi pakan atau feed conversion ratio (FCR) sebesar 1,3- 1,4 (Boyd dan Clay, 2002).

Minyak ikan merupakan salah satu sumber energi yang bisa digunakan untuk menambah nutrisi pada pakan udang. Minyak ikan juga kaya akan kandungan asam lemak tak jenuh rantai panjang, terutama asam lemak omega-3 (Rusmana et al., 2008). Lemak selain sebagai sumber energi juga berfungsi sebagai sumber asam lemak esensial (Halver \& Hardy, 2003). Asam lemak esensial adalah asam lemak yang tidak dapat disintesis oleh tubuh sehingga perlu ditambahkan melalui pakan.

Beberapa informasi tentang penambahan minyak ikan dalam pakan memiliki beberapa manfaat terutama untuk pertumbuhan seperti; pengaruh asam lemak esensial dan metabolisme pada pakan induk ikan sidat Asia Anguilla anguilla (Furuita et al., 2007); Penambahan minyak ikan pada pakan komersial terhadap pertumbuhan Anguilla (Retno, 2014); Tibbets et al. (2005) melaporkan bahwa kadar lemak sebesar 16\% dapat mengurangi penggunaan protein dari $51 \%$ menjadi $48 \%$ pada ikan A. rostrata ukuran 8 $\mathrm{g}$ dan menghasilkan kinerja pertumbuhan yang terbaik. Penelitian ini bertujuan untuk mendapatkan dosis terbaik penambahan minyak ikan pada pakan udang vannamei terhadap pertumbuhan dan FCR udang vannamei.

\section{STUDI LITERATUR}

Udang vannamei adalah hewan avertebrata air yang memiliki ruas-ruas dimana pada tiap ruasnya terdapat sepasang anggota badan. Anggota ini pada umumnya bercabang dua atau biramus. Tubuh udang secara morfologis dapat dibedakan menjadi dua bagian yaitu cepalothorax atau bagian kepala dan dada serta bagian abdomen atau perut. Haliman dan Adijaya (2005) menjelaskan bahwa udang vannamei memiliki tubuh berbuku-buku dan aktivitas berganti kulit luar (eksoskleton) secara periodik (moulting). Udang vannamei merupakan omnivora dan scavenger (pemakan bangkai). Makanannya biasanya berupa crustacea kecil dan polychaetes (cacing laut). Udang memiliki pergerakan yang terbatas dalam mencari makanan dan mempunyai sifat dapat menyesuaikan diri terhadap makanan yang tersedia di lingkungannya (Wyban dan Sweeney, 1991). 
Minyak ikan adalah salah satu zat gizi yang mengandung asam lemak kaya manfaat karena mengandung sekitar $25 \%$ asam lemak jenuh dan $75 \%$ asam lemak tak jenuh. Bila dibandingkan dengan hewan darat maka lemak pada hewan air memiliki komposisi asam lemak yang lebih kompleks yang terdiri atas asam lemak jenuh dari C14 sampai C-22 dan asam lemak tak jenuh dari satu hingga enam ikatan rangkap. Minyak ikan merupakan hasil ekstraksi lipid yang dikandung dalam ikan dan bersifat tidak larut dalam air.

\section{METODE}

Penelitian ini dilakukan pada bulan 27 Mei sampai 1 Juli 2018 selama 35 hari, di Desa Banyu Urip Kecamatan Ujung Pangkah Kabupaten Gresik. Penelitian ini bersifat eksperimental dengan metode penelitian Rancangan Acak kelompok (RAK) dengan 4 perlakuan, 3 kali ulangan dan 1 kontrol, dari setiap ulangan diambil secara acak 4 sampel. Setiap tempat budidaya ditebar benih udang vannamei ukuran $5-7 \mathrm{~cm}$ dengan kepadatan 20 ekor $/ \mathrm{m}^{3}$. Aplikasi minyak ikan pada setiap perlakuan pada pakan udang dengan konsentrasi sesuai perlakuan yaitu : $\mathrm{M}_{0}=\operatorname{Kontrol}(0 \mathrm{ml} / \mathrm{kg}), \mathrm{M}_{1}=5 \mathrm{ml} / \mathrm{kg} . \mathrm{M}_{2}=$ $10 \mathrm{ml} / \mathrm{kg}$ dan $\mathrm{M}_{3}=15 \mathrm{ml} / \mathrm{kg}$.

Parameter yang diamati dalam penelitian ini yaitu bobot mutlak (g), pertumbuhan panjang mutlak (cm), Feed Convertion Ratio (FCR). Data yang telah diperoleh dianalisis mengggunakan Sidik Ragam (ANOVA) dengan uji F pada selang kepercayaan $95 \%$, digunakan untuk menentukan apakah perlakuan berpengaruh nyata terhadap kelangsungan hidup. Apabila berpengaruh nyata, untuk melihat perbedaan antar perlakuan akan diuji lanjut dengan menggunakan uji BNT.

\section{HASIL DAN PEMBAHASAN}

Hasil penelitian bobot mutlak yang diperoleh dari masing-masing perlakuan disajikan dalam Gambar 1.

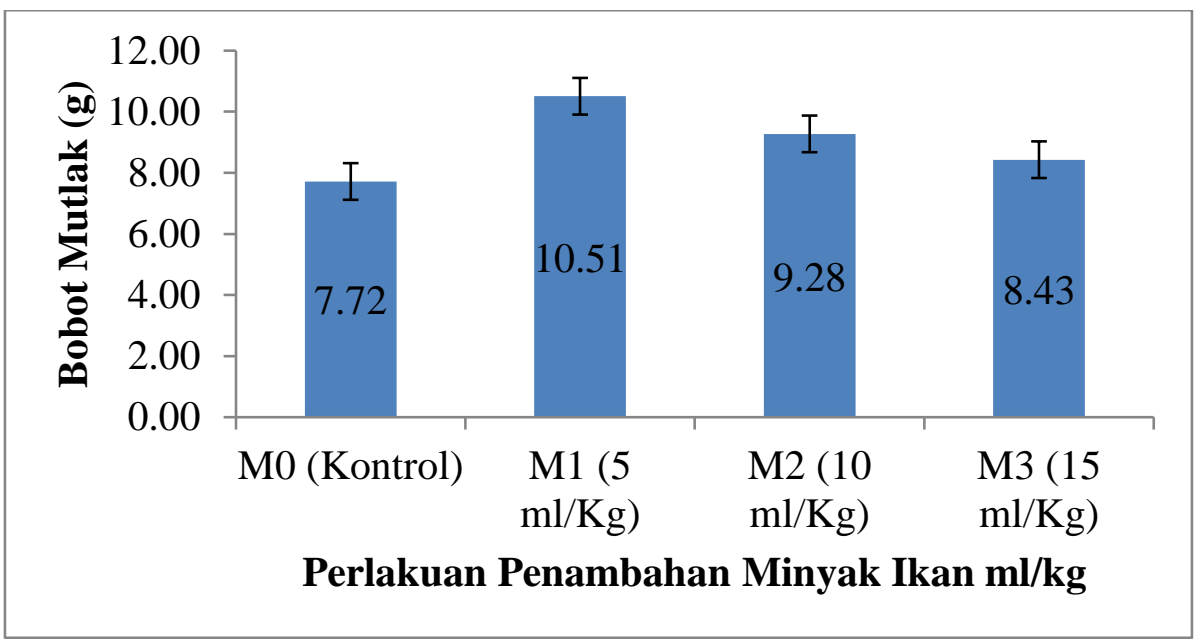

Gambar 1. Bobot mutlak (g) udang vannamei (Litopenaeus vannamei) selama penelitian. 
Gambar 1 menunjukkan bahwa bobot mutlak udang vannamei pada akhir penelitian perlakuan $\mathrm{M}_{0}$ (Kontrol) sebesar 7,72. Perlakuan $\mathrm{M}_{1}$ sebesar 10,51 sedangkan perlakuan $\mathrm{M}_{2}$ sebesar 9,28 dan perlakuan $\mathrm{M}_{3}$ sebesar 8,43. Hasil pertumbuhan bobot mutlak udang vannamei yang tertinggi yaitu pada perlakuan $\mathbf{M}_{1}$ dengan penambahan dosis minyak ikan sebanyak $5 \mathrm{ml} / \mathrm{kg}$ dan menghasilkan pertumbuhan bobot mutlak sebesar 10,51 gram. Sementara nilai pertumbuhan bobot mutlak udang vannamei yang terendah ditunjukkan pada perlakuan $\mathrm{M}_{0}$ dengan tanpa penambahan minyak ikan dan menghasilkan pertumbuhan bobot mutlak sebesar 7,72 gram.

Hasil penelitian panjang mutlak yang diperoleh dari masing-masing perlakuan disajikan dalam Gambar 2.

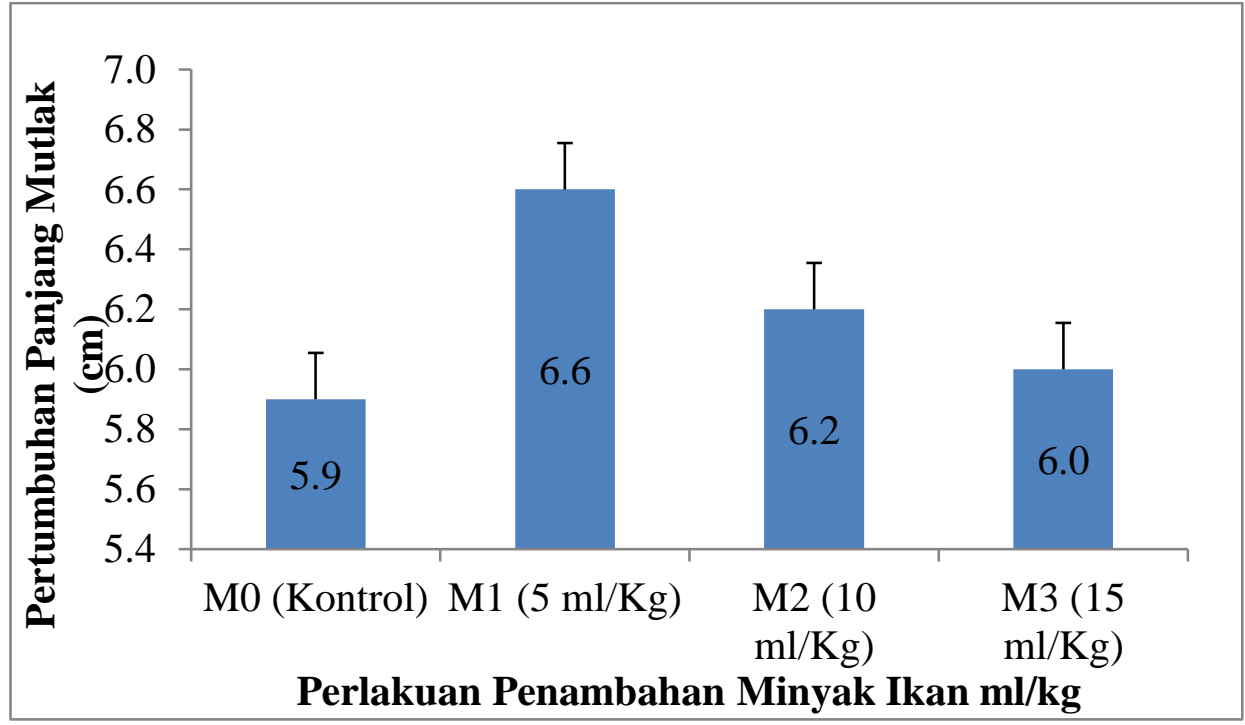

Gambar 2. Pertumbuhan Panjang Mutlak (cm) udang vannamei selama 35 hari penelitian.

Berdasarkan gambar 2, dapat disimpulkan bahwa pertumbuhan panjang mutlak udang vannamei pada perlakuan $\mathrm{M}_{0}$ sebesar 5,9 cm, pada perlakuan $\mathrm{M}_{1}$ sebesar 6,6 cm, pada perlakuan $\mathrm{M}_{2}$ sebesar $6,2 \mathrm{~cm}$, pada perlakuan $\mathrm{M}_{3}$ sebesar $6,0 \mathrm{~cm}$. Hasil pertumbuhan panjang mutlak udang vannamei yang tertinggi yaitu pada perlakuan $\mathrm{M}_{1}$ dengan penambahan dosis minyak ikan sebanyak $5 \mathrm{ml} / \mathrm{kg}$ dan menghasilkan pertumbuhan panjang mutlak sebesar $6,6 \mathrm{~cm}$. Sementara nilai pertumbuhan panjang mutlak udang vannamei yang terendah ditunjukkan pada perlakuan $\mathbf{M}_{0}$ dengan tanpa penambahan minyak ikan dan menghasilkan pertumbuhan panjang mutlak sebesar 5,9 $\mathrm{cm}$. 
Hasil penelitian penambahan minyak ikan dengan dosis yang berbeda pada pakan udang vannamei terhadap Feed Convertion Ratio (FCR), terdapat pada gambar 3.

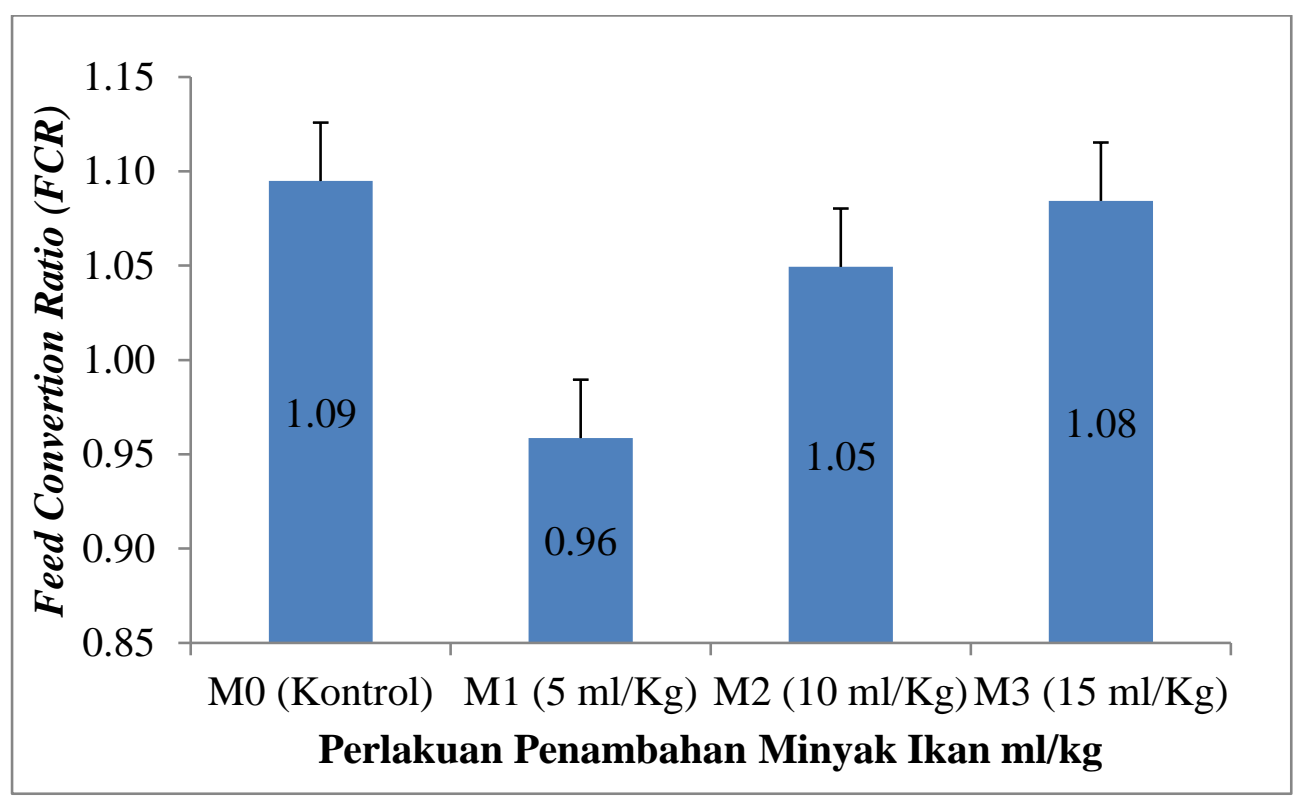

Gambar 3. Feed Convertion Ratio (FCR) udang vannamei pada akhir penelitian

Gambar 3 menunjukkan Feed Convertion Ratio (FCR) udang vannamei pada akhir penelitian. Nilai Feed Convertion Ratio (FCR) berbanding terbalik dengan berat, sehingga semakin rendah nilainya maka semakin efisien udang dalam memanfaatkan pakan menjadi pertumbuhan. Pada perlakuan $\mathrm{M}_{0}$ sebesar 1,10, perlakuan $\mathrm{M}_{1}$ sebesar 0,98 sedangkan perlakuan $\mathbf{M}_{2}$ sebesar 1,07 dan perlakuan $\mathbf{M}_{3}$ sebesar 1,1. Hasil Feed Convertion Ratio (FCR) udang vannamei yang terendah yaitu pada perlakuan $\mathrm{M}_{1}$ dengan penambahan dosis minyak ikan sebanyak $5 \mathrm{ml} / \mathrm{kg}$ dan menghasilkan Feed Convertion Ratio (FCR) sebesar 0,98. Sementara nilai Feed Convertion Ratio (FCR) udang vannamei yang tertinggi ditunjukkan pada perlakuan $\mathrm{M}_{3}$ dengan Penambahan minyak ikan pada pakan $15 \mathrm{ml} / \mathrm{kg}$ dan menghasilkan Feed Convertion Ratio (FCR) sebesar 1,1 .

\section{PEMBAHASAN}

Pada gambar1 perlakuan $\mathbf{M}_{1}$ berbeda sangat nyata dengan perlakuan $\mathbf{M}_{0}, \mathbf{M}_{2}$ dan $\mathbf{M}_{3}$. Peningkatan pertumbuhan diduga karena pemberian minyak ikan pada perlakuan $\mathrm{M}_{1}$ dengan dosis $5 \mathrm{ml} / \mathrm{kg}$ sudah memenuhi kebutuhan nutrisi udang vannamei. Sehingga kandungan nutrisi yang ada pada pakan dimanfaatkan udang untuk pertumbuhan. Affandi (2004) menyatakan makanan yang dikonsumsi oleh ikan akan mengalami suatu proses pencernaan hingga penyerapan, sehubungan dengan kekomplekan zat makanan dan keterbatasan kemampuan mencerna. 
Maka tidak semua makanan yang dikonsumsi dapat diserap oleh tubuh ikan melainkan dibuang sebagai feses sedangkan makanan yang terserap akan mengalami proses katabolisme, sehingga dapat menghasilkan energi bebas, energi bebas ini selanjutnya digunakan untuk proses penyusunan jaringan baru (pertumbuhan) dan proses lainnya dalam rangka menunjang kelangsungan hidup.

Lemak yang terkandung dalam minyak ikan dapat dimanfaatkan sebagai sumber energi bagi udang vannamei. Lemak memiliki kandungan energi $8-9 \mathrm{kkal} / \mathrm{g}$ (NRC, 1993) artinya lebih tinggi bila dibandingkan dengan kandungan energi protein dan karbohidrat yaitu 4,5 dan 4,0 kkal/g. Lemak dalam pakan sebagai salah satu nutrien yang diperlukan oleh ikan memiliki peran penting dalam tubuhnya. Selain sebagai sumber energi, lemak juga sebagai sumber asam lemak essensial yang merupakan salah satu komponen penting yang mempengaruhi pertumbuhan udang.

Hal ini menunjukkan bahwa perbedaan pertumbuhan bobot mutlak uji disebabkan karena perbedaan kandungan nutrisi yang diberikan yang menyebabkan rendahnya pertumbuhan organisme (Rahim, 2018; Rahim, 2018; Rahim et al., 2016; Rahim et al., 2015). Kelebihan nutrisi pakan juga dapat menyebabkan pertumbuhan rendah karena memerlukan energi yang besar untuk proses metabolisme sehingga pertumbuhan udang vannamei terhambat akibat kekurangan energi. Hal ini sesuai dengan NRC (2011) yang menyatakan bahwa pakan yang mengandung energi terlalu tinggi justru dapat membatasi jumlah pakan yang dikonsumsi ikan sehingga laju pertumbuhan menurun, karena membutuhkan energi yang besar untuk proses metabolisme.

Pada gambar 2, terlihat analisis ragam secara statistik diperoleh bahwa pemberian minyak ikan pada pakan udang vannamei terhadap panjang mutlak pada semua perlakuan tidak berbeda nyata $(\mathrm{p}<0,05)$. Namun demikian panjang rata-rata paling tinggi $6,6 \mathrm{~cm}$ pada perlakuan $\mathrm{M}_{1}$ dan terendah yaitu $5,9 \mathrm{~cm}$ pada perlakuan Mo.Sementara untuk nilai FCR udang vannamei selama penelitian dapat dilihat pada gambar 3. Tampak bahwa nilai FCR udang vannamei dari terendah sampai tertinggi yaitu $\mathrm{M}_{1}$ sebesar 0,98, $\mathrm{M}_{2}$ sebesar 1,07, $\mathrm{M}_{3}$ sebesar 1,1 dan $\mathrm{M}_{0}$ sebesar 1,10.

Hasil analisis variansi menunjukkan bahwa perlakuan yang diberikan berpengaruh nyata $(\mathrm{P}<0,05)$ terhadap FCR udang Hasil uji lanjut dengan menggunakan BNT menunjukkan bahwa $\mathrm{M}_{1}$ berbeda nyata terhadap $\mathrm{M}_{0}, \mathrm{M}_{2}$ dan $\mathrm{M}_{3}$. Rendahnya nilai FCR dengan pemberian minyak ikan dibanding tanpa pemberian minyak ikan diduga penyerapan nutrisi pada pakan udang bisa dimanfaatkan dengan baik untuk pertumbuhan. Makanan yang dikonsumsi oleh udang akan mengalami suatu proses pencernaan hingga penyerapan, sehingga nilai FCR rendah dan pertumbuhan meningkat. 
Kandungan lemak pada minyak ikan membantu proses pertumbuhan karena lemak dimanfaatkan udang untuk energi sedangkan protein untuk pertumbuhan. Nilai FCR tertinggi pada perlakuan $\mathrm{M}_{0}$ tanpa pemberian minyak ikan dibanding perlakuan $\mathrm{M}_{1}, \mathrm{M}_{2}$ dan $\mathrm{M}_{3}$ penambahan minyak ikan mendapat nilai FCR yang lebih baik. Mujiman (1995) kandungan lemak pakan ikan rata-rata berkisar antara 4- 18\% hal ini membuat pertumbuhan kurang optimal, karena kandungan lemak dalam pakan yang diberikan hanya cukup untuk pemeliharaan tubuh (maintenance) dan mengganti sel-sel yang rusak.

\section{KESIMPULAN}

Berdasarkan hasil penelitian yang telah dilakukan, maka dapat disimpulkan bahwa pemberian dosis minyak ikan pada pakan udang vannamei menunjukan perbedaan nyata pada variabel bobot mutlak dan FCR. Perlakuan $\mathrm{M}_{1}(5 \mathrm{ml} / \mathrm{kg}$ pakan) memberikan bobot mutlak dan FCR terbaik. Sedangkan variabel panjang mutlak tidak memperlihatkan perbedaan nyata pada semua perlakuan.

\section{DAFTAR PUSTAKA}

Affandi R, Djadja SS, Rahardjo MF, Sulistiono. 2004. Fisiologi ikan pencernaan dan penyerapan makanan. Departemen Manajemen Sumerdaya Perairan Faklutas Perikanan dan Ilmu Kelautan, Institut Pertanian Bogor.

Ahmad Mujiman. 1985. Makanan Ikan. Cetakan VII. Penerbit Penebar Swadaya. Jakarta.

Boyd, C.E., Clay, J.W. 2002. "Evaluation of Belize aquaculture LTD, A superintensive Shrimp aquaculture system", Report prepared under The World Bank,NACA, and FAO Consorsiu. Work in progress for Public Discussion. Published by The Consorsium. 17 pages.

Furuita H, Hori K, Suzuki, Sugita T, Yamamoto T. 2007. Effect of n-3 and n-6 fatty acids in broodstock diet on reproduction and fatty acid composition of broodstock and eggs in the Japanese eel Anguilla japonica. Aquaculture 267: $55-61$.

Haliman, R.W. dan D. Adijaya S. 2005. Udang Vannamei. Penebar Swadaya. Jakarta. $75 \mathrm{hlm}$.

Halver JE, Hardy RW. 2003. Fish Nutrition. New York: Academic Press.

Nababan, E., Putra I., dan Rusliadi. 2015. Pemeliharaan udang vannamei (Litopenaeus vannamei) dengan persentase pemberian pakan yang berbeda. Jurnal Ilmiah Perikanan dan Kelautan Vol. 3 No. 2. Universitas Riau. Kampus Bina Widya KM. 12,5 Simpang Baru Pekanbaru 282943. 
National Research Council (NRC), 1993. Nutrient Requirement of Fish. National Academy of science. Whasington D.C.

Rahim, A. R., Herawati, E. Y., Nursyam, H., Hariati, A. M. 2015. Cells Characteristics, Growth, and Quality of Gracilaria verrucosa Seaweed Production with Different Doses of Vermicompost Fertilizer. International Journal of Science Technology and Engineering, Volume 2, Issue 1.

Rahim, A. R., Herawati, E. Y., Nursyam, H., Hariati, A. M. 2016. Combination of Vermicompost Fertilizer, Carbon, Nitrogen and Phosphorus on Cell Characteristics, Growth and Quality of Agar Seaweed Gracilaria verrucosa. Nature Environment \& Pollution Technology, 15(4).

Rahim, A. R. 2018. Application of Seaweed Gracilaria verrucosa Tissue Culture using Different Doses of Vermicompost Fertilizer. Nature Environment and Pollution Technology, 17(2), 661-665.

Rahim, A. R. 2018. Utilization of Organic Wastes for Vermicomposting Using Lumbricus rubellus in Increasing Quality and Quantity of Seaweed Gracilaria verrucosa. Asian Journal of Microbiology, Biotechnology and Environmental Sciences. Volume 20, No. 2: 2018: S17 - S23.

Retno, C.M. 2014. Penambahan minyak ikan pada pakan komersial terhadap pertumbuhan Anguilla bicolor bicolor. Jurnal Akuakultur Indonesia 13 (1), 5460. Institut Pertanian Bogor. Jawa Barat

Rusmana, D., Piliang, W., Setiyono, A., and Budijanto, S. (2008). Minyak ikan lemuru dan suplementasi vitamin e dalam ransum ayam broiler sebagai imunomodulator. Animal Production, $10: 110-116$.

Tibbetts SM, Lall SP, Milley JE. 2005. Effects of dietary protein and lipid levels and DP DE ratio on growth, feed utilization, and hepatosomatic index of juvenile haddock Melanogrammus aeglefinus L. Aquaculture Nutrition 11: 67-75.

Wyban, J.A. dan Sweeney, J. N. 1991. Intensive Shrimp Production Technology. The Oceanic Institute. Hawai. USA. 